\title{
Materialities and Immaterialities in Art Historical Practices
}

Tutta Palin

The articles gathered here had their beginning in the conference organised by the Department of Art History at the University of Turku in co-operation with the Society for Art History in Finland, which was held on 28-29 November 2019 as the eighth National Conference in the field, TAHITI 8.

The late autumn days were darker and rainier than usual, but the atmosphere at the Sirkkala Campus in Turku was warm as an enthusiastic group of scholars and students from far and near came together to discuss questions pertaining to the state and future of art history as a discipline.

It should be added that the acronym "TAHITI" derives from the phrase Taidehistoria tieteenä (art history as a science), so the discrepancy between the title and the northern climate was at least partly unintentional.

The conference theme was From Material to Immaterial: Art Historical Practices in the Contemporary World (Materiaalisesta immateriaaliseen: taidehistoriallinen praksis tänään). When sending out the call for papers, we aimed to attract a broad spectrum of approaches, provoking debate by describing art history as a discipline in turmoil, traversed by a continuous flow of new currents of thought, wave after wave, up to the topical environmental turn. We articulated our starting point as follows: "Once grounded in the study of material objects and the worldviews embodied in them, art history now covers the study of dematerialised and ephemeral processes and complex interactions between incalculable numbers of actants as well." We asked how these changes have affected the practices of art history, transforming our research questions and choices of sources, as we continue to reframe and recontextualise the boundaries of our practice and field of study.

The response was positive, and in the end we enjoyed two inspiring keynote addresses, by Professor Dan Karlholm and Dr. Lynn Turner, and 24 paper presentations engaging in issues encompassing the range of interrelations of materiality and immateriality, the physical and the metaphysical, in the conceptions and practices of our field. Furthermore, the programme included receptions at the Turku Art Museum and the Wäinö Aaltonen Art Museum, and a visit to the Turku Cathedral, where Professor Visa Immonen kindly served as our guide. We cordially thank all the relevant parties, from speakers to local institutions and volunteers, for their generous contributions to this event.

This special bilingual issue of the TAHITI Journal is dedicated to the conference as

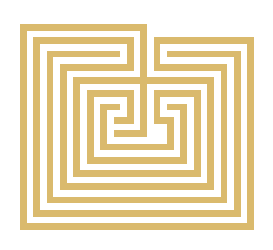


an expanded form of proceedings in which a selection of papers has been elaborated into full research articles. The perspectives include phenomenology and hermeneutics, deconstruction, new materialism, humananimal studies, critiques of ethnocentrism, visual semiotics and the intersection of art history and artistic research, with topics ranging from the 19th century to contemporary phenomena.

We are delighted to present contributions by both of our keynote speakers. With his keen, critical eye, Dan Karlholm reflects on the potential of the concept of assemblage as a transformative tool for art studies (sic), focused neither on art nor history, but instead on artworks, while Lynn Turner, in her imaginative poetic text, interrogates a set of obstinate Western binaries through the felicitous trope of the fig leaf. These are followed by Rahma Khazam's sensitive charting of shifts from the material to immaterial and back again in conceptual and digital art, challenging thus these art forms' alleged immateriality, and by Jane Vuorinen's analysis of contemporary artworks in which the signs of digital operations have been left visible, marking a process of co-creation with non- human systems. Altti Kuusamo's erudite, literary-informed analysis awakens haptic associations by way of focusing on the relationship between humans and the inanimate world in Giorgio de Chirico's (1888-1978) spatio-temporal evocations. Starting from Georges Didi-Huberman's concept of le visuel, poised between the visible and invisible, Ari Tanhuanpää, for his part, tackles what he sees as art history's generally inadequate understanding of the materiality of images.

From these philosophical positionings, we move to Tuija Hautala-Hirvioja's take on the problematics of materiality and immateriality through an intertextual analysis of artist Nils-Aslak Valkeapää's (1943-2001) ways of embracing Sami traditional knowledge amid modernisation. Carlos Idrobo's article takes up the phenomenon of bodily responses to paintings, leading us on a hermeneutical journey opening to a wide panorama from Romanticist classics to contemporary art. Likewise engaging in a methodological dialogue between art practices and art historical approaches, Kukka Paavilainen presents a detailed analysis of Ellen Thesleff's (1869-1954) cycle of prints and its material sources, re-encountered before an historical puppet theatre in situ in Venice.

Riikka Haapalainen has chosen as her topic contemporary participatory art, which time and again is conceptualised as a turn from the material to immaterial. Breaking from this, Haapalainen convincingly demonstrates how fundamentally dependent on the site-specific context (if also trans-situational relations) even this kind of an artistic "medium" is. We conclude with Ina Jessen's insightful reflections on contemporary artist Toni R. Toivonen's (b. 1987) "radical materialism" at the meeting point of a vanitas iconography and a process of organic decomposition, where the ephemeral nature of materiality is thought-provokingly highlighted through the physical transformation of an animal imprint.

We are proud to be able to present such a wealth of theoretical perspectives and case studies in evidence of the continuous transformative potential of our field — from art history to art studies, if you like.

Please enjoy!

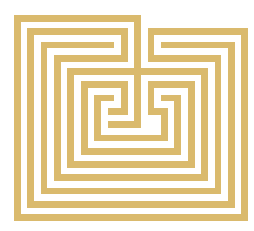

